Kan, M. O. ve Yeşiloğlu, F. (2017). Illk okuma yazma öğretiminde izlenen aşamalarda iki dilli çocukların yaşadıkları sorunlar ve bu sorunlara dair çözüm önerileri. Ana Dili Eğitimi Dergisi, 5(3), 519-533.

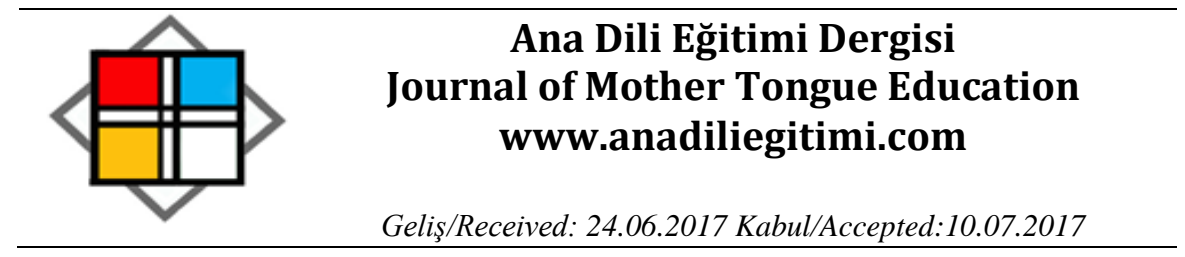

\title{
İlk Okuma Yazma Öğretiminde İzlenen Aşamalarda İki Dilli Çocukların Yaşadıkları Sorunlar ve Bu Sorunlara Dair Çözüm Önerileri
}

\author{
Mustafa Onur KAN* \\ Fülya YEŞILOĞLU**
}

Öz

Bu araştırmanın amacı, ilk okuma yazma öğretiminde izlenen aşamalarda iki dilli (Arapça ve Türkçe) çocukların yaşadıkları sorunları ve bu sorunlara dair çözüm önerilerini öğretmen görüşleri doğrultusunda belirlemektir. Olgubilim deseninde tasarlanan araştırmanın çalışma grubunu Hatay’ın iki dilli çocukların yoğun olarak bulunduğu ilçelerinden olan Defne ve Reyhanlı'da görev yapan 20 birinci sınıf öğretmeni oluşturmaktadır. Çalışmada veri toplama aracı olarak araştırmacılar tarafından geliştirilen Yarı Yapılandırılmış Görüşme Formu kullanılmıştır. Elde edilen veriler, betimsel analiz tekniği ile çözümlenmiştir. Araştırmaya katılan öğretmen görüşlerinden hareketle, iki dilli çocukların ilk okuma yazma öğretiminde izlenen aşamaların ("ilk okuma yazmaya hazırlık", "ilk okuma yazmaya başlama ve ilerleme" ve "bağımsız okuma ve yazma") tamamında çeşitli sorunlar yaşadıkları belirlenmiştir. Öğretmenlerin yarısı görsel okumada; yarıdan fazlası sesi hissetme ve tanıma, sesi/harfi okuma yazma, hece, kelime, cümle, metin oluşturmada; geneli de bağımsız okuma ve yazmada iki dilli çocukların sorun yaşadığını ifade etmiştir. Bununla birlikte araştırmaya katılan öğretmenlerin söz konusu sorunlara dair çözüm önerileri de ortaya koyulmuştur.

Anahtar kelimeler: illk okuma yazma öğretimi, ana dili, iki dillilik.

\section{Problems Experienced By Bilingual Children in the Early Reading and Writing Stages and Suggestions to Solve Those Problems}

\begin{abstract}
The aim of this study is to identify the problems experienced by bilingual (Arabic and Turkish) children in the early reading and writing stages and to propose solutions to solve those problems, based on teachers' views. Phenomenology research design was used in this study. The study group consisted of 20 first grade teachers, working in schools in Hatay's Reyhanlı and Defne counties where bilingual students reside heavily. In the study, a semi-structured interview form, developed by the researchers, was used as the data collection tool. The data obtained were analyzed, using the descriptive analysis technique. Based on the opinions of the teachers who participated in the study, it was determined that bilingual children experienced various problems in all stages of early reading and writing (i.e. "preparation for early reading and writing", "beginning early reading and writing and progressing, and "independent reading and writing"). Half of the teachers stated that bilingual children had problems in visual reading; more than half of the teachers stated that bilingual children had problems in perceiving and recognizing sounds, reading and writing the sounds/letters, and constituting syllables, words, sentences, and texts. The majority of the participating teachers stated that bilingual children had problems in independent reading and writing. Solutions suggested by the teachers to solve these problems were also presented.
\end{abstract}

Keywords: Early reading and writing instruction, mother tongue, bilingualism.

\footnotetext{
${ }^{*}$ Yrd. Doç. Dr., Mustafa Kemal Üniversitesi, Eğitim Fakültesi, Temel Eğitim Bölümü. Hatay. mokan@mku.edu.tr

${ }^{* *}$ Yüksek Lisans Öğrencisi, Mustafa Kemal Üniversitesi, Sosyal Bilimler Enstitüsü. Hatay
} 


\section{Giriş}

Ana dili, bireyin anne karnından başlayarak yaşadığı çevrede edindiği ve içselleştirdiği ilk dildir. Aksan'a (2015) göre ana dili, başlangıçta anneden ve yakın aile çevresinden, daha sonra da ilişkili bulunulan çevrelerden öğrenilen, insanın bilinçaltına inen ve bireyin bir toplumla en güçlü bağlarını oluşturan dildir. İki dillilik kavramını Tokdemir (1997), ana hatları ile iki veya birkaç dil sisteminin koşut öğrenilmesi ve gerektiğinde bir sistemden diğerine geçiş yapılması, Yılmaz (2014) ise çocuğun doğumdan itibaren iki dile aynı anda maruz kalması ve çocuğun her iki dili tek bir dilmiş gibi aynı anda kazanması olarak tanımlamaktadır.

İki dilliliğin çocuklar üzerinde olumlu ve olumsuz etkileri bulunabilmektedir. Wei'ye (2000) göre, iki dilli çocuklar bazı iletişimsel, kültürel ve bilişsel avantajlara sahip olabilmektedir. Bununla birlikte iki dillilik ile ilgili eğitim sistemlerinde yaşanan sorunlar; dil becerilerinin kazandırılması sürecinde iki dilliliğin öğrenme açısından olumsuz bir durum olarak algılanması, öğretmenlerin ve çocukların farklı dil yapılarını anlayıp ve ilişkilendirmekte zorluklar yaşaması ve iki dilli çocukların ailesinde ve okulda yaşadığı dil deneyimlerinin birbirinden farklı olması biçiminde ifade edilmektedir. (Martin, 1999'dan Akt. Belet, 2009). íki dilli çocuklar, evlerinde ve sosyal çevrelerinde genel olarak edindikleri ve içselleştirdikleri ana dillerini kullanmakta okula geldiklerinde ise ülkenin resmi dili olan ve kendi ana dillerinin dil yapısından farklı olan Türkçe ile eğitim aldıklarından çeşitli eğitim sorunları ile karşılaşabilmektedirler. Söz konusu eğitim sorunlarını ortadan kaldırmak ve ülkenin resmi dilini incelikleri ve güzellikleriyle çocuklara öğretmek genel anlamda eğitimin özel anlamda da Türkçe eğitiminin temel amaçlarındandır.

Illk okuma yazma öğretimi öğrencilerin hayat boyunca kullanacakları ve onlar için oldukça önemli bir yere sahip olan temel dil becerileri odaklı bir süreçtir. Akyol'a (2005) göre, ilk okuma yazmanın temel amaçları öğrencilere Türkçeyi doğru ve etkili kullanmalarını sağlayan okuma, yazma, konuşma, dinleme, görsel okuma ve sunu gibi temel becerileri kazandırarak Türk dilini sevdirmektir. Ses temelli cümle yönteminin esas alındığı Türkçe Dersi Öğretim Programı'nda (MEB, 2015) ilk okuma yazma öğretimi, aşağıdaki aşamalar izlenerek gerçekleştirilir:

1. Illk okuma yazmaya hazırlık

2. İlk okuma yazmaya başlama ve ilerleme

-Sesi hissetme, tanıma ve ayırt etme

-Harfi okuma ve yazma

-Harflerden heceler, hecelerden kelimeler, kelimelerden cümleler oluşturma

-Metin oluşturma 
ilk Okuma Yazma Öğretiminde İzlenen Aşamalarda İki Dilli Çocukların Yaşadıkları Sorunlar ve Bu Sorunlara Dair Çözüm Önerileri

\section{Bağımsız okuma ve yazma}

Yukarıda yer verilen aşamalar izlenerek gerçekleştirilen ilk okuma yazma öğretimi sürecinde ana dili Türkçe olan çocuklar söz konusu süreci daha rahat sürdürürken ana dili Türkçe olmayanlar bu süreçte bazı sorunlarla karşılaşabilmektedir. Alanyazında, Türkiye'deki iki dilli çocuklara Türkçe öğretimine ilişkin yapılan çalışmalar (örn. Aslan, Arslantaş ve Aslan, 2015; Belet, 2009; Gözüküçük, 2015; Susar Kırmızı, Özcan ve Şencan, 2016; Tulu 2009; Yılmaz ve Şekerci, 2016) yer almaktadır. Bununla birlikte iki dilli çocuklarla ilgili ses temelli cümle yöntemiyle ilk okuma yazma öğretiminde izlenen aşamaları kapsayan bir çalışmaya rastlanılmamıştır. Yalnızca cümle çözümleme yaklaşımıyla okuma yazma öğretiminde iki dillilerin yaşadıkları sorunları inceleyen Sarı́nın (2001) çalışması bulunmaktadır. Bu çalışmanın iki dilli çocukların ilk okuma yazma sürecine dair alanyazındaki tartışmalara ilk okuma yazma öğretiminde izlenen aşamalar üzerinden bir katkı sağlayabileceği düşünülmektedir. Bununla birlikte iki dilli çocuklara ilk okuma yazma öğreten sınıf öğretmenlerinin söz konusu süreçte çocukların yaşadıkları sorunlara dair görüşleri ve çözüm önerilerinin belirlenmesi benzer durumlardaki sınıf öğretmenlerine bir fikir verebilir.

Bu araştırmanın amacı, ses temelli cümle yöntemiyle ilk okuma yazma öğretiminde izlenen aşamalarda ("ilk okuma yazmaya hazırlık", "ilk okuma yazmaya başlama ve ilerleme" ve "bağımsız okuma ve yazma") iki dilli (Arapça ve Türkçe) çocukların yaşadıkları sorunları ve bu sorunlara ilişkin çözüm önerilerini öğretmen görüşleri doğrultusunda belirlemektir.

\section{Yöntem}

Bu çalışma nitel araştırma desenlerinden, farkında olunan fakat derinlemesine ve ayrıntılı bir anlayışa sahip olunmayan olgulara odaklanan olgubilim (Yıldırım ve Şimşek, 2016) deseninde tasarlanmıştır. Çalışmada ilk okuma yazma öğretiminde izlenen aşamalarda iki dilli çocukların yaşadıkları sorunlar ve söz konusu sorunlara ilişkin çözüm önerileri öğretmen görüşleri doğrultusunda değerlendirilmeye çalışıldığı için olgubilim deseninden yararlanılmıştır.

Araştırmanın çalışma grubunu 2016-2017 eğitim-öğretim yılında Hatay'ın iki dilli çocukların yoğun olarak bulunduğu ilçelerinden olan Defne ve Reyhanlı'da görev yapan 20 ilkokul birinci sınıf öğretmeni oluşturmaktadır. Araştırmaya katılan öğretmenlerin seçiminde, amaçlı örnekleme yöntemlerinden ölçüt örnekleme kullanılmıştır. Çalışma grubunun oluşturulmasında katılımcıların iki dilli çocuklara ilk okuma yazma öğretmiş olması ve birinci sınıf öğretmeni olmaları temel ölçüt olmuştur. Bu ölçütlere uyan 20 öğretmen rastlantısal olarak seçilmiştir. Araştırmaya katılan öğretmenlere dair bilgiler şu şekildedir:

On ikisi kadın, sekizi erkek olan öğretmenlerin on beşi sınıf öğretmenliği, ikisi sınıf öğretmenliği lisans tamamlama, birer öğretmen de sanat tarihi, Almanca öğretmenliği ve eğitim 
bilimleri programlarından mezundur. Ayrıca öğretmenlerin beşi 11-15, dördü 0-5, dördü 6-10, üçü 1620,2 'si $21-25$ ve 2'si 26-30 yıl arası mesleki deneyime sahiptir.

\section{Verilerin Toplanması}

Çalışmada veri toplama aracı olarak araştırmacılar tarafından geliştirilen Yarı Yapılandırılmış Görüşme Formu (YYGF) kullanılmıştır. Formun geliştirilmesinde öncelikle ilk okuma yazma öğretiminde izlenen üç aşamaya ("ilk okuma yazmaya hazırlık", "ilk okuma yazmaya başlama ve ilerleme" ve "bağımsız okuma ve yazma") dair on açık uçlu sorudan oluşan taslak bir form oluşturulmuştur. Formun kapsam ve yapı geçerliliğini sağlamak amacıyla belirtke tablosu hazırlanmış ve uzman görüşüne sunulmuştur. İki Türkçe eğitimi uzmanının belirtke tablosunu da göz önünde bulundurarak yaptıkları değerlendirmelerden sonra taslak formda bazı değişiklikler yapılmıştır. YYGF, çalışma grubundaki öğretmenlere uygulanmadan önce pilot uygulama olarak iki dillilere ilk okuma yazma öğreten üç birinci sınıf öğretmenine uygulanmıştır. Söz konusu pilot uygulama sonucunda formda yer alan soruların öğretmenler tarafından anlaşıldığı ve bir görüşmenin ortalama 45 dakika sürdüğü belirlenmiştir. Form, araştırmacılar tarafından 20 öğretmene uygulanmış ve veriler toplanmıştır.

\section{Verilerin Çözümlenmesi}

Elde edilen veriler, verilerin daha önceden belirlenen temalara göre özetlenip yorumlandığı betimsel analiz yöntemi (Yıldııım ve Şimşek, 2016) ile çözümlenmiştir. Bu araştırmada da veriler, ilk okuma yazma öğretiminde izlenen aşamaların temel alındığı araştırma sorularının oluşturduğu temalara göre incelenmiştir. Söz konusu incelemede değerlendirme birimi olarak cümle alınmıştır. Bu bağlamda ilk olarak formda yargı bildiren cümleler kodlanmıştır. Değerlendirme formuna her yeni yargı cümlesi kaydedilmiş, tekrarlanan cümlelerde ise önceki cümlenin yanına sıklık işareti eklenmiştir. YYGF'deki sorulardan elde edilen veriler, sıklık değerleri ve katılımcı görüşlerinden örnekler verilerek sunulmuştur.

\section{Bulgular}

Bu bölümde, araştırmada elde edilen bulgular ilk okuma yazma öğretiminde izlenen aşamalar "ilk okuma yazmaya hazırlık", "ilk okuma yazmaya başlama ve ilerleme" ve "bağımsız okuma ve yazma"ya ilişkin şekilde sunulmuştur.

Ilk okuma yazmaya hazırlık aşamasına ilişkin bulgular

Iki dilli çocuklarda görsel okumayı (okuma çalışmalarından önce çocukların görselleri tanıma, anlama, yorumlama ve ifade etme becerilerini) geliştirmede karşılaşılan sorunlar nelerdir? Bu sorunları ortadan kaldırmaya yönelik önerileriniz nelerdir? sorusuna yönelik öğretmenlerden $10^{\prime} \mathrm{u}$ 
İlk Okuma Yazma Öğretiminde İzlenen Aşamalarda İki Dilli Çocukların Yaşadıkları Sorunlar ve Bu Sorunlara Dair Çözüm Önerileri

sorun yaşandığını, 10’u sorun yaşanmadığını belirtmiştir. Öğretmenlere göre görsel okumayı geliştirme sürecinde karşılaşılan sorunlar şu şekildedir:

- Görseli yeteri kadar ifade edememe, kısa cümlelerle anlatmaya çalışma ( $f=6$ )

- Arapça ve Türkçe kelimeleri karıştırarak görseli ifade etme ( $f=2)$

- Görsellerdeki nesneleri Arapça söyleme ( $f=1)$

- Resmin tamamına değil bir kısmına odaklanma ( $f=1)$

Görsel okumayı geliştirme sürecinde sorun yaşayan öğretmenlerden biri "Görsel okuma yaparken çocuklar bana gösterdiğim resmin Arapçasını söylüyorlar. Örneğin ördek resmi gösteriyorum ve çocuklar bu resimde ne var diye soruyorum, aldığım cevap 'Batta Öğretmenim' (Ördek Ar. Batta) oluyor. Bu sorunu, anında düzeltmeler yaparak kelimenin doğrusunu söyleyerek aşmaya çalışıyorum." şeklinde görüş belirtmiştir.

iki dilli çocukların serbest çizgi ve düzenli çizgi çalışmalarında karşılaşılan sorunlar nelerdir? Bu sorunları ortadan kaldırmaya yönelik önerileriniz nelerdir? sorusuna yönelik öğretmenlerden 10’u sorun yaşandığını, 10'u sorun yaşanmadığını dile getirmiştir. Öğretmenlere göre çizgi çalışmalarında aşağıda belirtilen sorunlarla karşılaşılmaktadır:

- Kalemi doğru tutamama $(f=5)$

- Çizgileri satırdan taşırma $(\mathrm{f}=3)$

- Noktayı takip edememe $(\mathrm{f}=2)$

- Satırı sürdürememe $(\mathrm{f}=2)$

- Çabuk sıkılma $(f=2)$

- Yönergeleri doğru anlayamama ( $\mathrm{f}=2)$

Çizgi çalışmalarında çocukların kalemi doğru tutamamasını kaslarının yeterince gelişmemesine bağlayan öğretmenlerden biri görüşlerini şu şekilde açıklamıştır: "Çocukların genelinde kalem tutmada ve çizgi çalışmalarında sorun yaşanıyor. Çocukların hazırbulunuşlukları (kas gelişimi açısından) yeterli değildi. Serbest çizgide noktayı takip edememe, satırı sürdürememe ve çabuk sıkılıp kalemi bırakma sorunları oldu. Bu sorunları aşmak için kasları güçlendirmeye yönelik hamur, resim, kes yapıştır ve parmak egzersizleri yaptırdım." Öğretmenlerin yarısı öğrencilerin okul öncesi eğitim almalarının kas gelişimini destekleyeceğini ve böylelikle bundan kaynaklı sorunların en aza ineceğini düşünmektedir. Ayrıca bu sorunu aşmak için ince kasları geliştirici çalışmalara (el jimnastikleri, kesme yapıştırma, boncuk geçirme, hamur, resim, parmak egzersizleri vb.) ağırlık verdiklerini belirtmişlerdir.

Çocukların yönergeleri doğru anlamadığı için sorun yaşandığını düşünen öğretmenlerden biri "Söylediğim yönergelere uymakta zorlananlar oldu. Geri dön dediğimde geri dönmeyen direkt aşağı 
inen çocuklar oldu." şeklinde görüş bildirmiştir. Yine çocukların yönergeleri doğru anlamamasından dolayı çizgi çalışmalarında sorun yaşandığını düşünen bir öğretmen bu sorunu çözmek için yaptıklarını şu şekilde açıklamıştır: "Net ifadeler kullanılarak bu sorun çözülebilir. Kalemin ucunu göstererek 'noktanın üstüne koy, bir sonraki çizgiye git' gibi çok somut ifadelerle bu sorunu aşıyorum. Net ifadelerle kitaptaki yönergeleri birleştiriyorum. Böylece öğrenci okuma yazma öğrendiğinde kitap etkinliklerini yönergeleri rahat anlayarak yapabiliyor."

Ilk okuma yazmaya başlama ve ilerleme aşamasına ilişkin bulgular

iki dilli çocuklar sesi hissetme ve tanıma aşamasında hangi sorunları yaşıyorlar? (Örneğin sesin geçtiği varlığı bulmada) Bu soruna ilişkin önerileriniz nelerdir? sorusuna yönelik öğretmenlerden 12 'si çocukların sorun yaşadığını, 8'i sorun yaşamadığını dile getirmiştir. Öğretmenler sesi hissetme ve tanıma aşamasında aşağıdaki sorunlar ile karşılaşıldığını ifade etmiştir:

- Sesin kelimenin neresinde (başta, ortada, sonda) olduğunu bulmakta zorlanma ( $f=7$ )

- Kelimenin içinde sesin geçip geçmediğini bulamama $(f=2)$

- Sesin geçtiği resmi Arapça söyleme ( $f=1)$

- Kelimede aynı sesten iki tane varsa birine odaklanıp diğerini göz ardı etme ( $f=1)$

- Söylenene odaklanamama $(\mathrm{f}=1)$

Çocukların sesin kelimenin neresinde olduğunu bulmada sorun yaşadıklarını düşünen öğretmenler, çocukların sesi başta ve ortada rahat bulduğunu fakat sesi ortada bulmakta sorun yaşadıklarını dile getirmiştir. Ayrıca, bu sorunların özellikle ilk iki grupta yaşandığını belirtmiştir.

Bu konuda sorun yaşandığını dile getiren öğretmenlerden biri görsel okuma sürecinde de yaşanan soruna benzer şekilde görüşlerini açıklamıştır: "Evet bu konuda sorun yaşanıyor. Öğrencilerle bu aşamada çalışırken gösterdiğim resmin Arapça söylenişini bana söylüyorlar. Örneğin At resmi gösteriyorum bana Beygir diyor ya da Patates resmi gösteriyorum Kemaya diyor." Söz konusu öğretmen bu sorunun aşılması için, öncelikle kelimenin Türkçesini söylediğini ve yanlışları anında düzelttiğini belirtmiştir.

Araştırmaya katılan diğer öğretmenler de, sesi hissettirmeye yönelik video ve şarkılar kullanarak, görsellerden yararlanarak ve sesi bastırarak söyleyerek bu aşamada karşılaşılan sorunları ortadan kaldırdıklarını dile getirmiştir.

iki dilli çocuklar sesi /harfi okuma yazmada hangi sorunları yaşıyorlar? Bu soruna ilişkin önerileriniz nelerdir? sorusuna yönelik öğretmenlerden 14'ü çocukların sorun yaşadığını, 6'sı sorun yaşamadığını belirtmiştir. Araştırmaya katılan öğretmenlere göre bu konuda yaşanan sorunlar aşağıdaki şekildedir:

- Harfi doğru yazamama $(f=10)$ 
ilk Okuma Yazma Öğretiminde İzlenen Aşamalarda íki Dilli Çocukların Yaşadıkları Sorunlar ve Bu Sorunlara Dair Çözüm Önerileri

- Sesi doğru okuyamama $(f=9)$

- Harfi tersten yazma $(\mathrm{f}=1)$

- Kalemi doğru tutamama $(\mathrm{f}=1)$

- Harflerin noktalarını unutma $(\mathrm{f}=1)$

- Ünlüleri yazmama $(f=1)$

Sesi okumada sorun yaşandığını düşünen öğretmenler, Arapçanın etkisi nedeniyle sesin doğru çıkarılamadığını düşünmektedir. Bu konuda öğretmenlerden biri görüşlerini şu şekilde açıklamıştır: "Arapçadaki baskın sesler öne çıkıyor sesi okurken. Örneğin ilmittin'i Ğilmittin şeklinde sesletiyorlar. Bu da sesin istediğimiz şekilde okunmasının önüne geçiyor. Anında düzeltmeler yaparak bu sorunu ortadan kaldırmaya çalışıyorum."

Araştırmaya katılan öğretmenlerden biri bu sorunu şu şekilde aşmaya çalıştığını belirtmiştir: "Yazıdaki sorunları bire bir ilgilenerek çözmeye çalıstım. Okumadaki sorunları ise özellikle veli görüşmeleri yaparak velilere programı ve yöntemi kısaca anlatarak çocuklara yanlıs öğretimin önüne geçmeye çalıştım."

iki dilli çocuklar hece oluşturmada ne tür sorunlar yaşlyorlar? Bu soruna ilişkin önerileriniz nelerdir? sorusuna yönelik öğretmenlerden 14 'ü çocukların sorun yaşadığııı, 6'sı sorun yaşamadığını ifade etmiştir. Öğretmenlere göre hece oluşturmada yaşanan sorunlar şu şekildedir:

- Açık heceyi oluşturmada zorlanma $(\mathrm{f}=11)$

- Sesleri birleştirememe $(\mathrm{f}=5)$

- Heceyi yanlışokuma ( $f=3)$

- Heceyi anlamlandıramama ( $\mathrm{f}=2)$

- Heceyi doğru ayıramama $(f=1)$

Bu konuda sorun yaşandığını düşünen bir öğretmen karşılaştığı sorunu ve bu soruna dair çözüm önerisini şu şekilde ifade etmiştir: "ilk grupta hece oluştururken zorlanıldı. Nedeni, kapalı heceyi oluşturmalarına rağmen açık heceyi oluşturunca tersten okumaları. Yanlış okumalar oldu. Hece mantığı zor kavranıyor. 'El' öğrendi, 'ele' öğrendi. 'El ele' okudu. 'Ele' kapatılıp 'el' okutulunca bunu da el ele diye okuyor. 'Lale' okutulunca 'le' kapatılsa da 'Ia'yı 'Lale' diye okuyor. Ben bu sorunu alkış hecesi oyunu ile çözmeye çalışıorum. Alkış hecesi şu şekilde oluyor: Örneğin Lale kelimesini okuyacağız. La+le her heceye bir alkış yapıyoruz."

Öğretmenler, anında dönütte bulunarak, heceyi vurgulayarak, videolardan yararlanarak açık hece sorununu aşmaya çalıştıklarını dile getirmiştir. Bu konuda sorun yaşanmadığını düşünen 6 öğretmen de genelde anlamlı heceler oluşturmaya özen gösterdiklerini ve sesi hissettirme aşamasının başarı ile geçilmesinin hece oluşturma aşamasına katkı sağladığını dile getirmiştir. 
iki dilli çocuklar kelime oluşturmada ne tür sorunlar yaşıyorlar? Söz konusu sorunları ortadan kaldırmak için neler yapılabilir? sorusuna yönelik öğretmenlerden 14'ü çocukların sorun yaşadığını, 6'sı sorun yaşamadığını ifade etmiştir. Öğretmenlere göre yaşanan sorunlar şunlardır:

- Kelimeyi anlamlandırma sorunu $(f=6)$

- Karışık hecelerden kelime oluşturamama $(f=4)$

- Kelimeyi okuduktan sonra ilk heceyi unutma ( $\mathrm{f}=2$ )

- Çok heceli kelimeleri yazarken zorlanma $(f=2)$

- Kelimeyi okurken yaşanan sesletim sorunu $(\mathrm{f}=2)$

- Uzun kelimeleri okurken zorlanma $(\mathrm{f}=1)$

- Kelimeyi eksik sesle okuma ( $f=1)$

Kelimeyi anlamlandırma sorunu ile karşılaşan öğretmenler çocukların kelimeleri doğru yazıp okuduklarını fakat kelimelerin anlamını açıklayamadıklarını belirtmiştir. Bu konuda sorun yaşandığını düşünen bir öğretmen görüşlerini şu şekilde ifade etmiştir: "Yazılan kelimenin anlamını söylemede sorun yaşandı. Kelimeyi doğru yazıp okuyor ama anlamını bana açıklayamıyor. Bu sorunu aşmak için yazdırılacak kelimeyle ilgili ön bilgi verilebilir. Örneğin Ela kelimesi öğretilecekse bu kelimenin hem bir göz rengi ismi hem de özel bir ismi olduğu çocuklara öğretilebilir. Biz bu sorunu aşmak için öğrenilen kelimeyle ilgili resimler yaptık. Görsellerle kelimeleri destekledim. Bu şekilde kelime oluştururken yaşanan sorunları en aza indirmeye çalışıım."

Karışık hecelerden kelime oluşturmada sorun ile karşılaşan öğretmenlerden biri görüş ve çözüm önerisini şu şekilde açıklamaktadır: "Karışık heceleri anlamlı kelimelere çevirmede tereddütler yaşıyorlar. Acaba anlamlı kelime de biz mi bilmiyoruz, diye. Öğrencinin özgüvenini kırmamak adına ben yaptırıyorum. Bakın burada bir hece var, bu da onun arkadaşı. Hadi birleştirelim ne olacak diye. Oyunlaştırarak yapınca hem eğleniyorlar hem öğreniyorlar."

Kelime oluşturma aşamasında sorun yaşandığını düşünen öğretmenlerin bu sorunu çözmeye dair önerileri şunlardır:

- Tekerleme çalışmaları yapma

- Sayışma çalışmaları yapma

- Anında dönüt verme

- Bire bir çalışmalar yapma

- Heceleri renkli kâğıtlara kesip öğrenilen kelimenin boyamasını yapma

- Düzenli tekrar etme

- Okuma çalışmaları yapma

- Daha kısa kelimeler kullanma 
ilk Okuma Yazma Öğretiminde İzlenen Aşamalarda íki Dilli Çocukların Yaşadıkları Sorunlar ve Bu Sorunlara Dair Çözüm Önerileri

- Görsellerle kelimeleri destekleme

- Kelime anlamına yönelik çalışmalar yapma

- Hafıza güçlendirici çalışmalar yapma

- Hece sayısını kademeli bir şekilde artırarak kelime oluşturma

- Oyunlaştırarak kelime oluşturma

- Görsel dikte çalışmaları yapma

- Heceleri bastırarak söyleyeme

iki dilli çocuklar cümle oluşturmada ne tür sorunlar yaşıyorlar? Söz konusu sorunları ortadan kaldırmak için neler yapılabilir? sorusuna yönelik öğretmenlerden 14'ü çocukların sorun yaşadığını, 6'sı sorun yaşamadığını belirtmiştir. Öğretmenlere göre cümle oluşturmada karşılaşılan sorunlar şu şekildedir:

- Oluşturulan cümlenin anlamını çözememe $(\mathrm{f}=5)$

- Cümleleri devrik kurma $(\mathrm{f}=4)$

- Karışık kelimeleri anlamlı cümle yapamama ( $f=3)$

- Anlatım bozukluğu olan cümleler kurma $(f=3)$

- Cümlenin sonuna varınca başını unutma $(f=3)$

- Cümle sonlarına nokta koymama ( $f=2)$

- Birbirleriyle aynı cümleleri söyleme $(f=1)$

- Cümleyi büyük harfle başlatmama (f=1)

- Soru eki kullanmadan soru cümleleri oluşturma $(f=1)$

Çocukların cümle oluşturmada sorun yaşadığını düşünen öğretmenler bu durumu Arapça ile Türkçenin sözdizimsel yapısının farklı olmasına bağlamıştır. Öğretmenler bu konudaki görüşlerini şu şekilde açıklamıştır:

"Genellikle devrik cümle oluşturmaktadırlar. iki dilli öğrencilerde en çok yaşanan ve en önemli sorunlardan biridir. Arapçanın yapısal özelliğinden kaynaklı yüklemi başa alma problemi olmaktadır. Arapça düşünüp Türkçe cümle kurduğu için bu sorunu yaşıyoruz. Bu durumu aşmak için sık sık veli toplantıları yapmaktayız. Bu toplantılarda velilerden, evdeki iletişimlerinde kurdukları cümlelere dikkat etmeleri istenmektedir. Kurallı ve devrik cümle yapıları velilere anlatılarak kurallı cümleler kurarak iletişim kurmaları rica edilmektedir."

Cümle oluşturma aşamasında sorun yaşandığını düşünen öğretmenlerin bu sorunu çözmeye dair önerileri şu şekildedir:

- Veli toplantıları ile velilerin evdeki konuşmalarında kurallı cümleler kurmalarını tavsiye etme

- Dikte çalışmaları yapma 
- Cümleyi yanlış kullanan öğrencinin yanlışını sınıfça düzeltme çalışması

- Tahtaya karışık kelime kartonları asma bunları cümleye çevirmelerini isteme

- Cümlenin ne olduğu hakkında bilgi verme ve örnekler yapma

- Nokta, virgül ve soru işaretinin kullanımını gösteren materyallerin hazırlanması

- Videolu anlatımlardan yararlanma

- Resimli dikte çalışmaları yapma

- Öğretilen kelimelerle cümleler oluşturma

- Türkçenin dil yapısını içselleştirme amacıyla hikâye okutma, film izletme çalışmaları yapma

- Cümleleri canlandırma çalışmaları yapma

- Cümlelerdeki nesneleri görselle destekleme

- Kelime sayısını kademeli bir şekilde artırma iki dilli çocuklar metin oluşturmada ne tür sorunlar yaşıyorlar? Söz konusu sorunları ortadan kaldırmak için neler yapılabilir? sorusuna yönelik öğretmenlerden 13'ü çocukların sorun yaşadığını, 7'si sorun yaşamadığını dile getirmiştir. Metin oluşturmada yaşanan sorunlar aşağıda belirtilmiştir:

- Okudukları metni anlayamama $(\mathrm{f}=7)$

- Bir konu ile ilgili fikirlerini yazamama $(f=5)$

- Olayları anlamlı sıraya koyamama $(\mathrm{f}=1)$

- Sayfa düzenini sağlayamama ( $f=1)$

Görüşme yapılan öğretmenler metin oluşturmada en çok yaşanan sorunlardan birinin çocukların bir konu ile ilgili fikirlerini yazamaması olduğunu belirtmektedir. Öğretmenler çocukların fikirlerini tam olarak organize edemeden bir konuyu anlattıklarını, bu kopukluğun da metin oluşturma girişimlerini olumsuz etkilediğini düşünmektedir. Bu konuda sorun yaşandığını düşünen öğretmenlerden biri görüş ve çözüm önerisini şu şekilde dile getirmiştir:

"Giriş gelişme ve sonuç bölümlerinde sorun var. Olayı anlatırken gelişmeden başlıyor, sonuca gidiyor sonra girişe geliyor. Anlatım bütünlügünde sorun var. Yazma çalışmaları yaparak bu sorunu aşmaya çalışıoruz."

Araştırmaya katılan öğretmenlerden üçü, metin oluşturma sürecindeki sorunları ortadan kaldırmak için çocuklara öğrendikleri ve bildikleri kelimelerle başta kısa metinler kurdurduklarını dile getirmiştir.

Bağımsız okuma ve yazma aşamasına ilişkin bulgular

iki dilli çocuklar bağımsız okumada ne tür sorunlar yaşıyorlar? Söz konusu sorunları ortadan kaldırmak için neler yapılabilir? sorusuna yönelik öğretmenlerden $15^{\prime} \mathrm{i}$ çocukların sorun yaşadığını, $5^{\prime} \mathrm{i}$ 
ilk Okuma Yazma Öğretiminde İzlenen Aşamalarda íki Dilli Çocukların Yaşadıkları Sorunlar ve Bu Sorunlara Dair Çözüm Önerileri

sorun yaşamadığını ifade etmiştir. Öğretmenlere göre bu konuda yaşanan sorunlar aşağıdaki şekildedir:

- Yavaşokuma ( $\mathrm{f}=9)$

- Kelimeyi değiştirerek okuma ( $\mathrm{f}=4)$

- Heceleyerek okuma ( $\mathrm{f}=2)$

- Vurgu ve tonlamaya dikkat etmeden okuma $(f=2)$

- Okuduğunun anlamını anlatamama $(f=1)$

- Sesleri doğru birleştirememe $(f=1)$

- Son heceyi önce söyleme ( $f=1)$

- Okuduklarına odaklanamama $(\mathrm{f}=1)$

- Noktada durmama $(f=1)$

- Düşük ses tonu ile okuma $(f=1)$

- Uzun kelimelerde ilk heceleri unutma $(\mathrm{f}=1)$

- Okurken satır atlama $(\mathrm{f}=1)$

- Heceyi uzatarak okuma ( $\mathrm{f}=1$ )

Bağımsız okumada en çok yaşanan sorun olan yavaş okumayı öğretmenler çocukların sesleri birleştirmeyi tam olarak anlayamamalarına, kelimeyi ses ses birleştirmeye çalışmalarına bağlamıştır.

Öğretmenlerin bağımsız okumada karşılaşılan sorunları ortadan kaldırmak için başvurdukları çözüm yolları ise şunlardır:

- Evde ve sınıfta okuma çalışma

- Okuma yarışmaları yapma

- Her gün bire bir okuma çalışmaları yapma

- Eve ek etkinlikler verme

- Velilere nasıl okutmaları gerektiği hakkında bilgi verme

- Tekerleme çalışmaları yapma

- Şiir çalışmaları yapma

- Dikte çalışmaları yapma

- Hızlı okuma çalışmaları yapma

- Örnek okumalar yapma

- Göz egzersizleri yapma

- Videolu çalışmalar yapma

iki dilli çocuklar bağımsız yazmada ne tür sorunlar yaşıyorlar? Söz konusu sorunları ortadan kaldırmak için neler yapılabilir? sorusuna yönelik öğretmenlerden 17'si çocukların sorun yaşadığını, 3’ü sorun yaşamadığını belirtmiştir. Bağımsız yazmada karşılaşılan sorunlar şunlardır: 
- Ünlüleri eksik yazma $(f=5)$

- Harflerin ebatlarını ayarlayamama $(f=4)$

- Cümle sonuna nokta koymayı unutma $(\mathrm{f}=4)$

- Sayfa düzenini sağlayamama $(\mathrm{f}=4)$

- Harflerin noktalarını unutma $(\mathrm{f}=3)$

- Bazı harfleri birbiriyle karıştırma $(\mathrm{f}=2)$

- Yavaş yazma $(\mathrm{f}=2)$

- Resimli diktede görselin Türkçesini bilmedikleri için yazamama ( $f=1)$

- Heceleri eksik yazma $(f=1)$

Bağımsız yazma aşamasında sorun yaşandığını düşünen öğretmenlerden biri görüş ve çözüm önerisini şu şekilde dile getirmiştir: "Yazarken bazı harfleri atlama sorunu ile karşılaştım. Ben 'atıyordu' kelimesini yazmalarını istedim ama kendileri 'atlyodu' (genellikle ünlüler ve $r$ harfi eksik) yazıyorlardı. Kelimeleri yazdıırken özellikle $r$ sesini bastırarak söyledim ve eksik yazanları anında düzeltmeye çalıştım."

Bu konuda sorun yaşandığını belirten öğretmenler, söz konusu sorunları aşmak için şu çalışmaları yapmaktadır:

- Tahtada yazılan metni seslendirme ardından bakarak yazma

- Kısa metin yazma ödevleri verme

- Ekstra çalışmaları, bire bir kontroller ve renkli kalemlerle düzeltme

- Kelimeleri yazdırırken sesleri bastırarak söyleme

- Yanlışı hemen sildirip doğrusunu yazdırma

- Dikte yaparken cümle bitince "nokta" diye hatırlatma

- Bire bir ilgilenme

- Yanlışları anında düzeltme

- Hece hece bastırarak söyleme

- Tahtada bireysel yazma çalışmaları

- Dikte çalışmaları yapma

- Tahtadakini yazma çalışması

Bağımsız yazma konusunda sorun yaşamayan öğretmenler ise bu konuda sorun yaşamamalarını ilk gruptan itibaren yapılan dikte, hece diktesi ve çocuklara kendi cümlelerini yazdırma çalışmaları yapmalarına bağlamıştır. 
illk Okuma Yazma Öğretiminde İzlenen Aşamalarda İki Dilli Çocukların Yaşadıkları Sorunlar ve Bu Sorunlara Dair Çözüm Önerileri

\section{Tartışma ve Sonuç}

Bu çalışmada, Türkçe Dersi Öğretim Programı'nda (MEB, 2015) ses temelli cümle yöntemiyle ilk okuma yazma öğretiminde izlenen "ilk okuma yazmaya hazırlık", "ilk okuma yazmaya başlama ve ilerleme" ve "bağımsız okuma ve yazma" aşamalarında iki dilli çocukların yaşadıkları sorunlar ve bunlara dair çözüm önerileri öğretmen görüşleri doğrultusunda incelenmiştir. Araştırmada ulaşılan temel sonuca göre, söz konusu aşamaların tamamında sorunlar yaşandığı belirlenmiştir. Benzer şekilde Sarı'nın (2001) çalışmasında da iki dilli çocukların cümle çözümleme yöntemi ile okuma yazma öğrenirken hazırlık, cümle, kelime, hece, ses ve serbest okuma yazma devrelerinde ana dili Türkçe olan çocuklara göre daha fazla sorun yaşadıkları ve bu sorunları daha uzun sürede aşabildikleri tespit edilmiştir. Her iki ilk okuma yazma öğretimi yaklaşımında da sorunlar yaşandığı görülmektedir. Bu durumda çocukların Arapçayı Türkçeden daha fazla kullanmalarının ve Türkçeden farklı yapısal özellikteki Arapçanın etkisi olduğu düşünülmektedir. İki dilli çocukların Türkçeyi daha yaygın kullanmaları ve ilk okuma yazma öğretiminde izlenen aşamalara dair ek çalışmalarla sorunlar en aza indirilebilir. Çalışmada ulaşılan diğer sonuçlar aşağıda tartışılmıştır.

Görsel okuma aşamasında en çok karşılaşılan sorun çocukların görseli yeteri kadar açıklayamamaları, kısa cümlelerle anlatmaya çalışmaları ve görsellerdeki nesneleri Arapça ifade etmeleri şeklindedir. Çocukların Türkçe kelime dağarcıklarının Arapçaya göre az olmasının, onları görselleri Arapça ifade etmeye yönelttiği düşünülmektedir. Çocukların anne karnındaki dönemden itibaren mümkünse yalnızca Arapçaya maruz kalmamaları, Arapça kadar Türkçe dilsel girdiye maruz kalmaları onların Türkçeyi daha rahat ve doğru kullanabilmelerini sağlayabilir.

Öğretmenlere göre serbest çizgi/ düzenli çizgi çalışmalarında en çok karşılaşılan sorunlar çocukların el kaslarının kalem tutacak kadar gelişmemiş olması, çizgileri satırdan taşırma ve satırı sürdürememedir. Bu sorun, temelde iki dillilikten bağımsız şekilde çocukların yazma için gerekli olan psikomotor becerilerinin söz konusu çalışmaları yapmaya yetecek kadar gelişmemiş olmasına bağlanabilir. Bununla birlikte bazı öğretmenler iki dilli çocukların tek dillilerden ayrı olarak yönergeyi anlamadıklarını belirtmiştir. Okul öncesi eğitim, çocukları zihinsel gelişim ve psikomotor gelişim açısından birinci sınıfa hazırladığından özellikle iki dillilerin okul öncesi eğitim alarak birinci sınıfa başlamaları; çalışmaları doğru bir şekilde sonuna kadar sürdürebilme ve yönergeleri anlama konusundaki sorunları azaltabilir.

Sesi hissetme ve tanıma aşamasında öğretmenlerin yarıdan fazlası, çocukların sesin kelimenin neresinde olduğunu bulma çalışmalarında sesi başta ve sonda rahatlıkla bulabildiğini, ancak ortada bulmakta sorun yaşadıklarını belirtmiştir. Çocukların söylenen kelimeyi konuşma dilinde az kullanmaları, söz konusu kelimeye aşina olmamaları ve bu sebeple kelimeye tam olarak 
odaklanamamalarının anılan sorunda etkisi olabilir. Sesi/harfi okuma yazma aşamasında ise çocukların bazı sesleri tam olarak çıkaramamasının veya bazı harfleri tam olarak okuyamamasının Arapça ile Türkçe arasındaki farklılıklardan kaynaklandığı düşünülmektedir. Demirci'nin (2015) çalışmasında da bu görüşü destekleyen bulgulara ulaşılmıştır. Araştırmaya katılan öğretmenlerin sesi/harfi okuma yazma aşamasında karşılaşılan sorunları; çocukların hatalarını anında düzelterek, onlarla bire bir ilgilenerek ve velilerle -çocuklara yanlış öğretmemeleri için- görüşmeler yaparak aşmaya çalıştıkları belirlenmiştir.

Hece oluşturma aşamasında öğretmenlerin yarıdan fazlası sorun yaşandığını ifade etmiştir. Öğretmenler çocukların kapalı heceyi oluştururken çok sorun yaşamadığını, fakat kapalı heceye bir ünlü eklenerek oluşturulan açık hecelerde sorunlar yaşandığını düşünmektedir. Benzer şekilde Acat ve Özsoy (2006) ana dili Türkçe olan çocuklarda da açık hece elde etmede sorun yaşandığını bulgulamıştır. Öğretmenin kapalı heceden açık heceye ulaşmada süreci doğru yürütememesi bu sorunun sık görülmesinde bir etken olabilir. Araştırmaya katılan öğretmenler, anında dönütte bulunarak, heceyi vurgulayarak ve videolardan yararlanarak açık hece sorununu aşmaya çalıştıklarını ifade etmiştir. Hem araştırmaya katılan öğretmenlerin çözüm önerilerinden yararlanılarak hem de kapalı heceden açık heceye ulaşmada süreç doğru yürütülerek söz konusu sorunlar en aza indirilebilir.

Öğretmenlerin yarısı, çocukların kelime, cümle ve metin oluşturmada sorunlar yaşadığını belirtmiş̧tir. Kelime oluşturmadaki sorunlar, cümle ve metin oluşturmayı doğrudan etkilediği için öncelikle bu sorunun azaltılması gerekmektedir. Kelime oluşturmaya ilişkin olarak öğretmenler çocukların karışık heceleri anlamlı bir kelimeye çevirmede zorlandıklarını ifade etmişlerdir. Görsel ağırlıklı kelime oyunları ile Türkçe kelime dağarcıklarının artırılması bu sorunun azalmasına katkı sağlayabilir. Cümle oluşturma aşamasında ise, çocukların devrik cümleler kurmaları, oluşturulan cümle devrikse bunu kurallı cümleye çevirememe ve soru eki kullanmadan soru cümleleri oluşturma sorunları ile karşılaşıldığı belirlenmiştir. Arapçanın yapısal farklılıklarından kaynaklı bu sorunlar, çocukların Türkçe kurdukları cümlelere de yansımaktadır. Garcia ve Ortiz (1988) çocukların resmi dille başladıkları cümleyi kendi dilleriyle tamamlayabildiklerini ve bu durumun normal bir özellik olmakla beraber dilin yanlış öğrenilmesine neden olabileceğini belirtmektedir. Okuma yazma aşamasına geçmeden önce hikâye dinleme, film izleme ve diyaloğa dayalı konuşma çalışmaları ve resimli dikte çalışmaları yapmanın çocuğun Türkçenin dil yapısını içselleştirmesine katkısı olabileceği düşünülmektedir.

Bağımsız okuma ve yazma aşamalarında öğretmenlerin geneli sorun yaşandığını belirtmiştir. Bağımsız okumada en çok karşılaşılan sorunun çocukların metni -anlamayı engelleyecek düzeydeyavaş okumalarıdır. Bu sorunda çocukların kelime tanıma ve ayırt etmede zorluklar yaşamalarının etkisi olabilir. Öğretmenler çocukların beş harften uzun kelimelerde paniklediklerini ifade etmiştir. 
İlk Okuma Yazma Öğretiminde İzlenen Aşamalarda İki Dilli Çocukların Yaşadıkları Sorunlar ve Bu Sorunlara Dair Çözüm Önerileri

Dolayısıyla onların aşina oldukları ve çok uzun olmayan kelimelerin yer aldığı metinlerden yararlanılması sorunun çözümüne katkı sağlayabilir. Bağımsız yazmaya ilişkin olarak da, öğretmenler temel yazma sorunlarının -örneğin kelimelerdeki ünlüleri eksik yazma- bağımsız yazmada önemli sorunlar oluşturduğunu belirtmiştir. Öğretmenlerin, çocuklara anında dönüt vermesi ve onlarla bire bir çalışması söz konusu sorunların ortadan kalkmasına katkı sağlayabilir.

\section{Kaynaklar}

Acat, M. B. ve Özsoy, U. (2006). Ses temelli cümle yöntemiyle ilk okuma yazma öğretiminde karşılaşılan güçlükler, Ulusal Sınıf Öğretmenliği Kongresi Bildiri Kitabı (ss. 15-37), Gazi Üniversitesi, Ankara.

Aksan, D. (2015). Her yönüyle dil ana çizgileriyle dilbilim. Ankara: TDK Yayınları.

Akyol, H. (2005) Türkçe ilk okuma yazma öğretimi. Ankara: PegemA Yayınları.

Aslan, Ü., Arslantaş, í. ve Aslan, í. (2015). Ana dili Türkçe olmayan öğrencilere ilk okuma- yazma öğretiminde öğretmenlerin karşılaştıkları güçlükler. International Journal of Languages' Education and Teaching. $2704-2716$

Belet, Ş. D. (2009). íki dilli Türk öğrencilerin ana dili Türkçeyi öğrenme durumlarına ilişkin öğrenci, veli ve öğretmen görüşleri (Fjell illköğretim Okulu örneği, Norveç) Selçuk Üniversitesi Sosyal Bilimler Enstitüsü Dergisi, 21, 71-85.

Demirci, M. (2015). B1 seviyesinde Türkçe öğrenen Suriyeli öğrencilerin sesli okuma becerisiyle ilgili tespitler. International Periodical For The Languages, Literature and History of Turkish or Turkic, 10 (7), 333-358.

Garcia, S.B. \& Ortiz, A. A. (1988). Preventing inappropriate referrals of language minority students to special education. New Focus Series No. 5. Wheaton, MD: National Clearinghouse for Bilingual Education.

Gözüküçük, M. (2015). Anadili Türkçe olmayan ilkokul öğrencilerine ilkokuma yazma öğretiminde karşılaşılan sorunlar ve çözüm önerileri. Denizli: Pamukkale Üniversitesi, Yayınlanmamış Doktora Tezi.

MEB (2015). Türkçe Dersi (1-8. Sınıflar) Öğretim Programı. Ankara.

Sarı, M. (2001). iki dilli çocukların çözümleme yöntemiyle okuma- yazma öğrenirken karşılaştıkları güçlükler. Adana: Çukurova Üniversitesi, Yayınlanmamış Yüksek Lisans Tezi.

Susar Kırmızı, F., Özcan, E. ve Şencan, D. (2016). Türkçenin az konuşulduğu bölgelerde ilk okuma yazma sürecinde karşılaşılan sorunlara ilişkin öğretmen görüşleri. Uluslararası Türkçe Edebiyat Kültür Eğitim Dergisi, 5 (1), 412-445.

Tokdemir, A. (1997). Dil edinimi ve yabancı dil. Ankara: Sam Yayınları.

Tulu, Y. (2009). Ana dili Türkçe olan ve ana dili Türkçe olmayan (iki dilli) 4-7 yaş çocukların dil düzeyine etki eden faktörlerin incelenmesi. Konya: Selçuk Üniversitesi, Yayınlanmamış Yüksek Lisans Tezi.

Yıldırım, A. ve Şimşek, H. (2016). Sosyal bilimlerde nitel araştırma yöntemleri. Ankara: Seçkin Yayınclık

Yılmaz, M. Y. (2014). ỉki dillilik olgusu ve Almanya'daki Türklerin iki dilli eğitim sorunu. Turkish Studies, 9 (3), 1641-1651.

Yılmaz, F. ve Şekerci, H. (2016). Ana dil sorunsalı: Sınıf öğretmenlerinin deneyimlerine göre ilkokul öğrencilerinin yaşadıkları sorunlar. Eğitimde Nitel Araştırmalar Dergisi, 4 (1), 47-63

Wei, L. (2000). The bilingualism reader. New York: Routledge. 